\title{
DEVELOPMENT OF ALGORITHM FOR RETRIEVAL OF CHLOROPHYLL-a AND SUSPENDED SEDIMENT CONCENTRATIONS FOR COASTAL ENVIRONMENT USING IRS - P4 OCM DATA
}

\author{
Nagalakshmi R. ${ }^{1}$, Ramalingam M. ${ }^{2}$, SanthiDevi R. ${ }^{3}$, Vidya Priya V. ${ }^{4}$, Subbaraj L. ${ }^{5}$ \\ ${ }_{1,2,4,5}$ Research Scholar, Institute of Remote Sensing, Anna University, Chennai, India \\ ${ }^{3}$ Center for Remote Sensing \& Geo Informatics, Sathyabama University, Chennai, India \\ Email: 'nagalakshmi_r1978@yahoo.co.in
}

\begin{abstract}
Chlorophyll-a and suspended sediment are two important parameters of case II water quality. In case I water, these two parameters can be effectively quantified by empirical algorithm developed using the radiance values obtained from remote sensing data through the surface concentration samples collected from the field. In case II waters, however, the task becomes difficult due to the presence of anthropogenic activities. This paper explores the usefulness of remote sensing technology for analysis of chlorophyll-a (chl-a) and suspended sediment (SS) by developing an algorithm for two seasons using IRS-P4 OCM sensor. The algorithm has been validated and variation between the field and computed value is round $5 \%$. This algorithm can be used to estimate the chlorophyll-a and suspended sediment concentration in the coastal environment using the IRS-P4 OCM sensor without any field sample values for further analysis.
\end{abstract}

Key words: Chlorophyll-a, Suspended sediment, Vedaranyam coastal wetland, algorithm, OCM sensor.

\section{INTRODUCTION}

Chlorophyll-a is used as the primary pigment-index for various phytoplanktons in water and is needed for estimating primary productivity, biomass etc. Suspended sediment are the most common type of pollutants both in terms of weight and volume in the surface of coastal water systems and helpful in determining water dynamics and spread of pollutants (Ritchie et al, 1990). They can be an effective measure of tropic status, are potential indicators of maximum photosynthetic rate and are commonly used as a measure of water quality.

Water color remote sensing is applied more and more widely in the water quality monitoring of oceanic, coastal and inland water body because it has many advantages, such as wide range, synchronization and low cost for data collection (Camphell, 1988; Zhao, 2000; Claudia, 2001). Morel \& Prieur (1977) classified water body as two types: case I water body, which is Open Ocean; case II water body, which is coastal, estuary and inland water body. Now the inversion research of case I water body is correspondingly mature and the accuracy of inversing model is mainly chlorophyll and suspended sediment. And that of case II water body is very difficult due to the interaction of many water components, such as suspended sediment, chlorophyll and yellow substance etc. Remote sensing of coastal water quality (case II water body) has involved mainly in estimation of surface chlorophyll-a and suspended sediment from sensorderived radiance. This is because of the fact that, these two parameters are optically active and can adequately represent the coastal water quality scenario.
In this study Ocean Color Monitor (OCM) sensor data obtained from IRS P4 satellite has been used to estimate surface chlorophyll-a and suspended sediment concentration at the Vedaranyam coast. The OCM of the Indian Remote Sensing Satellite IRS P4 is primarily designed for aquatic application. It is endowed for watercolor remote sensing and it is the best available source of data for monitoring coastal water quality due to its higher spatial resolution $(360 \mathrm{~m})$. In this study an attempt has been made to develop an algorithm for estimating the chlorophyll-a and suspended sediment concentration in the lagoon and coastal environment respectively.

\section{STUDY AREA}

Vedaranyam, area endowed with coastal wetland Fig. 1 located at the southern end of the Cauvery delta and

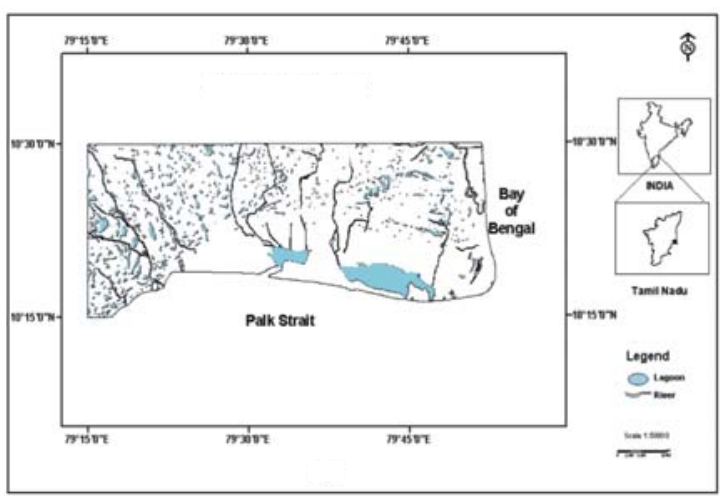

Fig. 1. Study Area Map 
also on the southeastern coast of Tamil Nadu is considered for this case study. It lies in Thirutharaipoondi and in parts of Mannarugudi, Pattukottai taluks of erstwhile Thanjavur district of Tamil Nadu. It falls within the co-ordinates of latitude $1015^{\prime} \mathrm{N}$ to $1025^{\prime} \mathrm{N}$ and longitude $7920^{\prime} E$ to $7955^{\prime} E$. Many drainage arteries of the Cauvery basin namely, Paminiuar, Koraiar, Kilaithangiyar, Marakakoraiar flow through Muthupet and adjacent villages and create a lagoon before they empty into the Palk Strait. A dense mangrove community occupies the northern as well as the western border of the lagoon. A sandpit forms the southern portion of the lagoon, which is devoid of mangroves.

\section{METHODOLOGY:}

Surface water samples were collected using Van Dorn water sampler on the dates of $17^{\text {th }}$ and $19^{\text {th }}$ November 2003 for monsoon season and $28^{\text {th }}$ and $30^{\text {th }}$ April of 2004 for summer season from 12 sampling points for coastal environment Fig. 2.

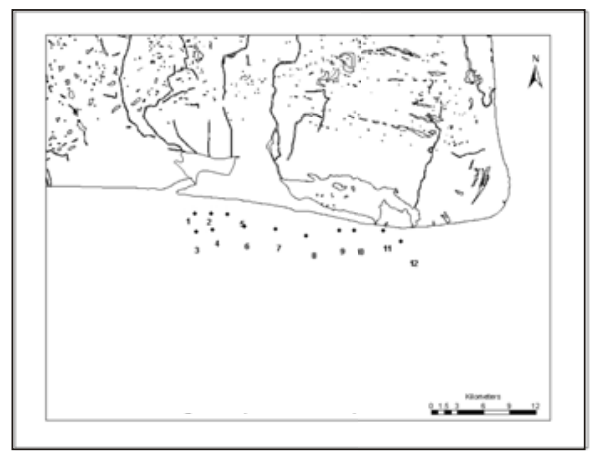

Fig. 2. Sample Location Map

at the time of satellite overpass and the OCM sensor data were collected for the same dates from NRSA and are used in the analysis. All the samples were collected between 11.30pm to 1.30pm which coincide with the IRSP4 satellite overpass. Out of the twelve samples, eight samples were selected for development of algorithm and four samples were used for validation. (Table 1 and Table 2).

Table 1(a). Samples Selected for Development of Algorithm (Chlorophyll-a)

\begin{tabular}{|c|c|c|c|c|c|c|}
\hline $\begin{array}{l}\text { Sampling } \\
\text { points }\end{array}$ & Longitude & Latitude & band2 & band5 & band6 & $\begin{array}{l}\text { Field Chl-a } \\
\left(\mathrm{mg} / \mathrm{m}^{3}\right)\end{array}$ \\
\hline L1 & $79^{\circ} 29^{\prime} 47^{\circ} \mathrm{E}$ & $10^{\circ} 17^{\circ} 07^{\circ} \mathrm{N}$ & 26 & 88 & 88 & 2.06 \\
\hline L2 & $79^{\circ} 31^{\prime} 05^{\circ} \mathrm{E}$ & $10^{\circ} 17^{\prime} 27^{\circ} \mathrm{N}$ & 37 & 92 & 95 & 2.31 \\
\hline L3 & $79^{\circ} 32^{\prime} 14^{\circ} \mathrm{E}$ & $10^{\circ} 15^{\prime} 55^{\circ} \mathrm{N}$ & 47 & 78 & 102 & 2.08 \\
\hline L4 & $79^{\circ} 33^{\prime} 06^{\circ} \mathrm{E}$ & $10^{\circ} 16^{\prime} 12^{-2} \mathrm{~N}$ & 52 & 86 & 68 & 2.44 \\
\hline L5 & $79^{\circ} 33^{\prime} 28^{\circ} \mathrm{E}$ & $10^{\circ} 1722{ }^{\circ} \mathrm{N}$ & 82 & 93 & 102 & 2.34 \\
\hline L6 & $79^{\circ} 34^{\prime} 51^{\circ} \mathrm{E}$ & $10^{\circ} 16^{\prime} 53^{\circ} \mathrm{N}$ & 33 & 142 & 99 & 2.36 \\
\hline L7 & $79^{\circ} 43^{\prime} 32^{\circ} \mathrm{E}$ & $10^{\circ} 15^{\prime} 56^{\prime \prime} \mathrm{N}$ & 44 & 99 & 87 & 2.46 \\
\hline L8 & $79^{\circ} 42^{\prime} 02^{\circ} \mathrm{E}$ & $10^{\circ} 15^{\prime} 42^{\prime} \mathrm{N}$ & 57 & 79 & 54 & 2.73 \\
\hline
\end{tabular}

Table 1(b). Samples Selected for Validation

\begin{tabular}{|c|c|c|c|c|c|c|c|c|c|}
\hline $\begin{array}{l}\text { Samplin } \\
\text { g points }\end{array}$ & Longitude & Latitude & $\mathrm{dn} 2$ & dn5 & dn6 & $\begin{array}{c}\text { Field } \\
\text { Chl-a } \\
\left(\mathrm{mg} / \mathrm{m}^{3}\right)\end{array}$ & $\begin{array}{l}\text { Computed } \\
\text { chl-a } \\
\left(\mathrm{mg} / \mathrm{m}^{3}\right)\end{array}$ & $\begin{array}{l}\text { Difference } \\
\text { chl-a } \\
\left(\mathrm{mg}^{3} \mathrm{~m}^{3}\right)\end{array}$ & $\begin{array}{l}\text { Difference } \\
\text { in } \%\end{array}$ \\
\hline$L 9$ & $\begin{array}{l}79^{\circ} 40^{\circ} \\
20^{\circ} \mathrm{E}\end{array}$ & $\begin{array}{l}10^{\circ} 16^{\prime} 02 \\
{ }^{\prime} \mathrm{N}\end{array}$ & 37 & 82 & 111 & 2.09 & 1.97 & 0.12 & 5.7 \\
\hline L10 & $\begin{array}{l}79^{\circ} 44^{\prime} \\
20^{\circ} \mathrm{E}\end{array}$ & $\begin{array}{l}10^{\circ} 15^{\prime} \\
46^{\prime \prime} \mathrm{N}\end{array}$ & 33 & 47 & 74 & 2.03 & 2.15 & 0.12 & 5.91 \\
\hline L11 & $\begin{array}{l}79^{\circ} 36^{\prime \prime} \\
06^{\circ} \mathrm{E}\end{array}$ & $\begin{array}{l}10^{\circ} 16^{\prime \prime} \\
10^{\circ} \mathrm{N}\end{array}$ & 29 & 52 & 69 & 2.35 & 2.21 & 0.14 & 5.95 \\
\hline L12 & $\begin{array}{l}79^{\circ} 37^{\prime} \\
11^{\circ} \mathrm{E}\end{array}$ & $\begin{array}{l}10^{\circ} 16^{\prime} \\
20^{\circ} \mathrm{N}\end{array}$ & 41 & 59 & 74 & 2.38 & 2.25 & 0.12 & 5.04 \\
\hline
\end{tabular}

Table 2(a). Samples Selected for Development of Algorithm (Suspended Sediment)

\begin{tabular}{|c|c|c|c|c|c|}
\hline $\begin{array}{l}\text { Sampling } \\
\text { points }\end{array}$ & Longitude & Latitude & band2 & band5 & Field SS (mg/L) \\
\hline L1 & $79^{\circ} 29^{\prime} 4 T^{\circ} \mathrm{E}$ & $10^{\circ} 17^{\prime} 07^{\prime \prime N}$ & 142 & 134 & 10.17 \\
\hline L2 & $79^{\circ} 31^{\prime} 05^{\circ} \mathrm{E}$ & $10^{\circ} 17^{\prime} 27^{\prime \prime N}$ & 135 & 127 & 9.11 \\
\hline L3 & $79^{\circ} 32^{\prime} 14^{\prime \prime} \mathrm{E}$ & $10^{\circ} 15^{\prime} 55^{\prime \prime} \mathrm{N}$ & 142 & 186 & 10.01 \\
\hline L4 & $79^{\circ} 33^{\prime} 06^{\circ} \mathrm{E}$ & $10^{\circ} 16^{\prime} 12^{\prime \prime} \mathrm{N}$ & 106 & 142 & 10.19 \\
\hline L5 & $79^{\circ} 33^{\prime} 28^{\circ} \mathrm{E}$ & $10^{\circ} 17^{\prime} 22^{*} \mathrm{~N}$ & 145 & 139 & 10.42 \\
\hline L6 & $79^{\circ} 34^{\prime} 51^{\circ} \mathrm{E}$ & $10^{\circ} 16^{\prime} 53^{\prime} \mathrm{N}$ & 162 & 165 & 10.23 \\
\hline L7 & $79^{\circ} 43^{\prime} 32^{\circ} \mathrm{E}$ & $10^{\circ} 15^{\prime} 56^{\prime \prime} \mathrm{N}$ & 179 & 134 & 9.65 \\
\hline L8 & $79^{\circ} 42^{\prime} 02^{\circ} \mathrm{E}$ & $10^{\circ} 15^{\prime} 42^{\prime \prime} \mathrm{N}$ & 126 & 152 & 9.87 \\
\hline
\end{tabular}

Table 2(b). Samples Selected for Validation

\begin{tabular}{|c|c|c|c|c|c|c|c|c|}
\hline $\begin{array}{l}\text { Sampling } \\
\text { points }\end{array}$ & Longitude & Latitude & Band4 & Band5 & $\begin{array}{c}\text { Field } \\
\text { SS } \\
(\mathrm{mgl})\end{array}$ & $\begin{array}{l}\text { Compute } \\
\mathrm{dSS} \\
\text { (mgl) }\end{array}$ & $\begin{array}{l}\text { Differenc } \\
\text { e SS } \\
\text { (mgl) }\end{array}$ & $\begin{array}{l}\text { Difference } \\
\text { in } \%\end{array}$ \\
\hline L9 & $\begin{array}{l}79^{\circ} 40^{\prime \prime} \\
20^{\circ} \mathrm{E}\end{array}$ & $\begin{array}{l}10^{\circ} 16^{\prime} 02 \\
\mathrm{~N}\end{array}$ & 131 & 124 & 10.39 & 9.80 & 0.59 & 5.67 \\
\hline L10 & $\begin{array}{l}79^{\circ} 44^{\prime} \\
20^{\circ} \mathrm{E}\end{array}$ & $\begin{array}{l}10^{\circ} 15^{\prime} \\
46^{\circ} \mathrm{N}\end{array}$ & 120 & 143 & 9.54 & 9.96 & -0.42 & -4.40 \\
\hline L11 & $\begin{array}{l}79^{\circ} 36^{\prime} \\
06^{\circ} \mathrm{E}\end{array}$ & $\begin{array}{l}10^{\circ} 16^{\prime} \\
10^{\circ} \mathrm{N}\end{array}$ & 119 & 154 & 10.69 & 10.05 & 0.64 & 5.98 \\
\hline L12 & $\begin{array}{l}79^{\circ} 37^{\prime} \\
11^{\circ} \mathrm{E}\end{array}$ & $\begin{array}{l}10^{\circ} 16^{\prime} \\
20^{\circ} \mathrm{N}\end{array}$ & 147 & 132 & 9.24 & 9.83 & .0 .59 & -6.38 \\
\hline
\end{tabular}

Using OCM DAS software chlorophyll-a and SS values obtained for further validation of these algorithms. Fig. 3, 4, 5, 6 .

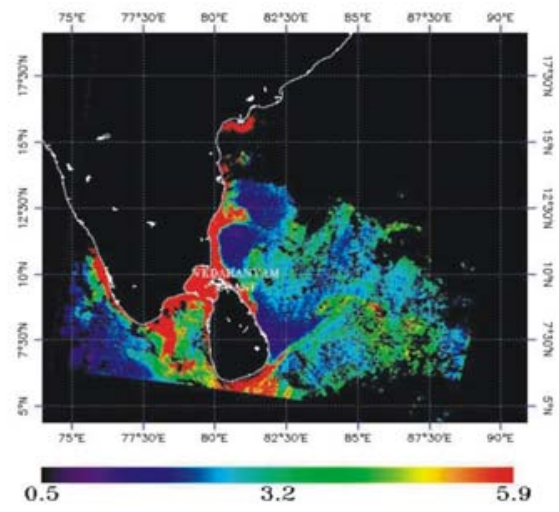

Fig. 3. OCM - Sensor Data for Chlorophyll-a in Summer Season 


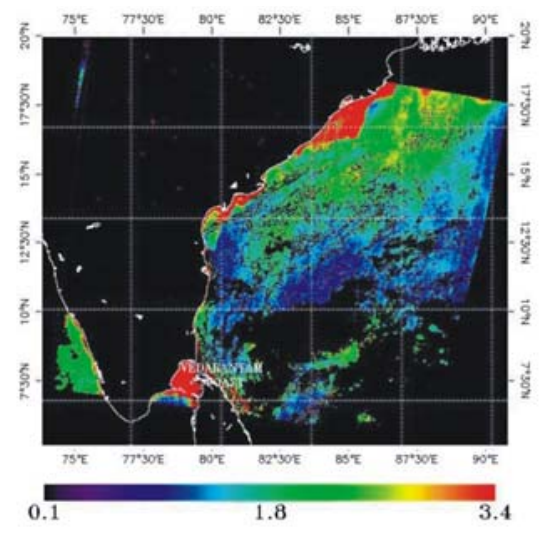

Fig. 4. OCM - Sensor Data for Chlorophyll-a in Monsoon Season

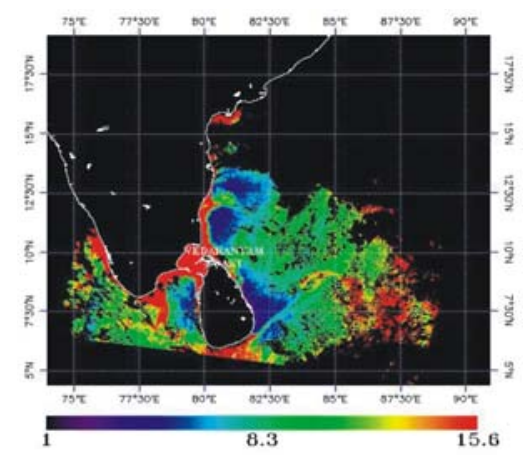

Fig. 5. OCM - Sensor Data for Suspended Sediment in Summer

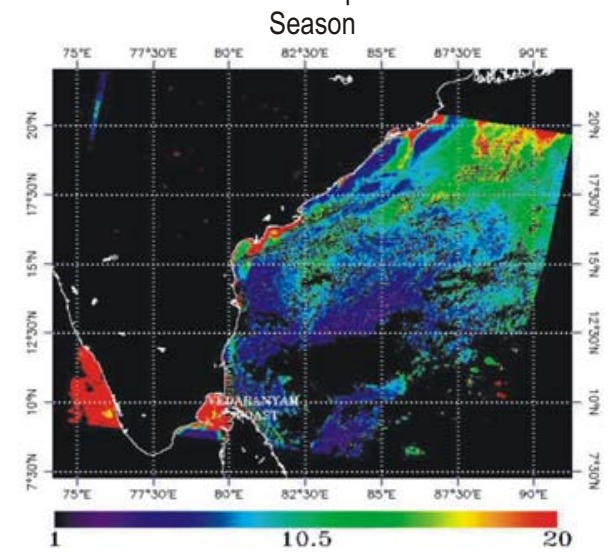

Fig .6. OCM - Sensor Data for Suspended Sediment in Monsoon Season

The chlorophyll-a concentrations were estimated by using the spectrophotometer 6300 Jensey at the Aquatic laboratory. The chlorophyll-a concentration was measured by using the technique and calculation described by Parsons et.al (1989). Known volumes of water $(500 \mathrm{ml}-1000 \mathrm{ml})$ were filtered through a filter paper (Millipore, size $0.5 \mathrm{~mm}$ ). As the water is being filtered, a few drops of suspension of magnesium carbonate were added to prevent acidity on the filter. Pigments were extracted from the filters in $90 \%$ acetone. The wavelengths involved are $750 \mathrm{~nm}, 664 \mathrm{~nm}, 647 \mathrm{~nm}$, and 630nm.
Suspended particulate materials (dry weight $\left(\mathrm{mg} \mathrm{L}^{-1}\right)$ ) were determined gravimetrically as outlined in Strickland and Parsons (1972) and as specified in JGOFS protocols [UNESCO 1994]. Samples were filtered through $0.4 \mu \mathrm{m}$ pre-weighed polycarbonate filters. The filters were washed with three $2.5-5 \mathrm{ml}$ aliquots of distilled water and immediately dried in an oven at $75^{\circ} \mathrm{C}$. The filters were then re-weighed in laboratory, using an electrobalance.

The OCM scenes were corrected for atmospheric effects of Rayleigh and aerosol scattering using an approach called long wavelength atmospheric correction method. The approach used the two near infrared channels at 765 and $865 \mathrm{~nm}$ to correct for the contribution of molecular and aerosol scattering in visible wavelengths at 412, 443, 490, 510, and $555 \mathrm{~nm}$ (Gordon and Wang, 1994). The water leaving radiances derived after atmospheric corrections were used to compute chlorophyll-a and suspended sediment concentration.

Using MATLAB version 8.6 multiple regression analysis was made in between the spectral signature obtained from OCM data and the field sample values of chlorophyll-a and suspended sediments concentration. While developing the algorithm often sets remote sensing data as independent variables and concentration of water quality components as dependent variables to construct their equations.

\section{RESULTS AND DISCUSSION}

Different algorithms are developed separately for Chlorophyll-a and Suspended Sediment concentration. The multiple regression equations developed are given below.

\section{Chlorophyll-a algorithm development}

Empirical algorithms have been developed using MATLAB software by cubic polynomial regression between log10 (Rrs490/Rrs555) and in-situ chlorophyll values.

$$
\begin{aligned}
& \text { a. Algorithm for monsoon season: } \\
& \text { Chl-a }=1.4773-13.8496 X-66.3435 X^{2}-93.6687
\end{aligned}
$$$$
X^{3}
$$

b. Algorithm for summer season

$$
\text { Chl-a }=3.7137-0.4381 X-9.4726 X^{2}-11.7168 X^{3}
$$

Where,

$$
\begin{aligned}
& \text { Chl-a }=\text { chlorophyll-a concentration } \mathrm{mg} / \mathrm{m}^{3} \\
& \quad \mathrm{x}=\log _{10} 0^{(\mathrm{R}} \mathrm{rs}^{(490) / R} \mathrm{rS}^{(555)]} \\
& { }^{\mathrm{R}} \mathrm{rS}=\text { remote sensing reflectance values }
\end{aligned}
$$




\section{Suspended sediment algorithm development}

The suspended sediment algorithms have been developed by linear regression plots between the natural logarithm of Xs and the same of in-situ suspended sediment values.

a. Algorithm for monsoon season:

$$
S S=10.3523-0.2106 \mathrm{Xs}
$$

b. Algorithm for summer season

$$
S S=7.3445+0.3999 X s
$$

Where,

$$
\begin{aligned}
& \text { SS }=\text { suspended sediment concentration } \mathrm{mg} / \mathrm{l} \\
& X s=(\operatorname{Rrs555+Rrs670)})^{*}(\operatorname{Rrs} 490 / \operatorname{Rrs} 555)
\end{aligned}
$$

Where Chl-a is the chlorophyll-a concentration in $\mathrm{mg} / \mathrm{m}^{3}$, SS is the suspended sediment concentration in $\mathrm{mg} / \mathrm{l}$ and $\mathrm{dn}$ is the digital value corresponding to band numbers. These algorithms can be used for estimating the chlorophyll-a and suspended sediment concentration in quantitatively with respect to $\mathrm{dn}$ values of OCM data.

The chlorophyll-a and the suspended sediment concentrations were retrieved from the developed algorithms for coastal environment. The computed values were slightly varied from field values.

In monsoon season, the computed chl-a values varied from 0.1 to $0.69 \mathrm{mg} / \mathrm{m}^{3}$ Fig. 7 ., SS values varied from 0.42 to $0.89 \mathrm{mg} / \mathrm{L} \mathrm{Fig.} \mathrm{8.} \mathrm{In} \mathrm{summer} \mathrm{season,} \mathrm{chl-a}$ varied from 0.8 to $0.95 \mathrm{mg} / \mathrm{m}^{3} \mathrm{Fig}$. 9 . SS varied from 0.52 to $1.15 \mathrm{mg} / \mathrm{L}$ Fig. 10. compared to the field values. The average difference varied from 4 to 7 in percentage.

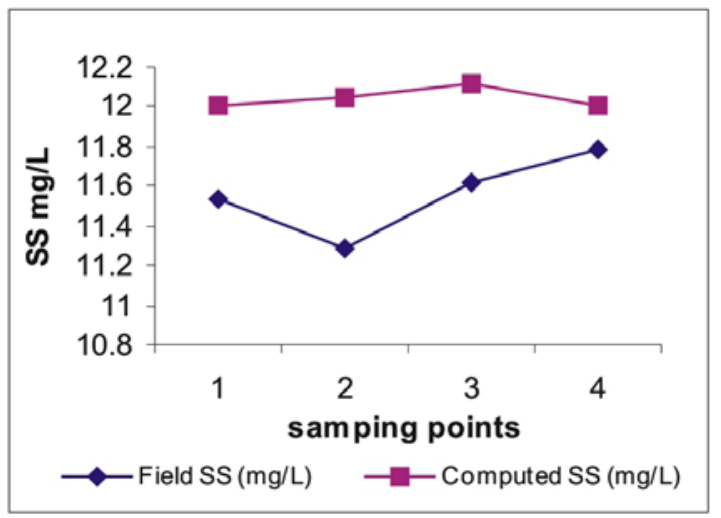

Fig. 7. Chl-a values comparison between field values and computed values in monsoon season.

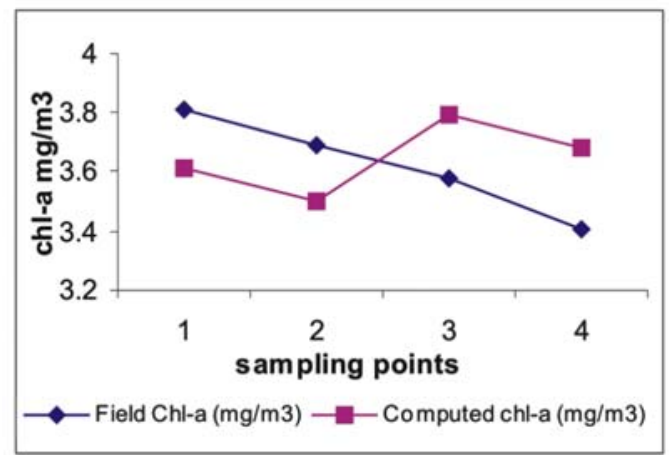

Fig. 8. SS values comparison between field values and computed values in monsoon season.

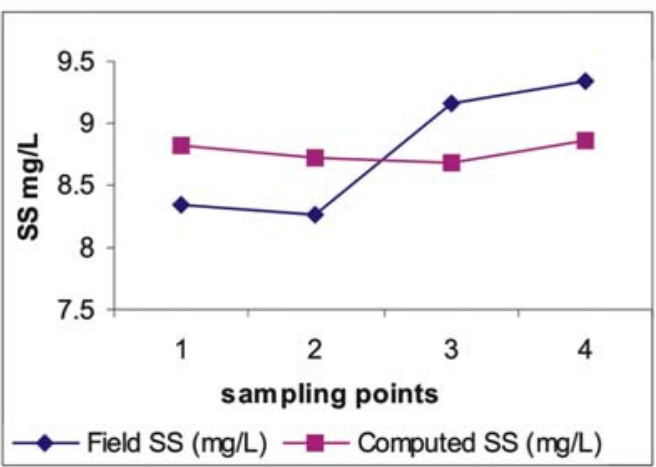

Fig. 9. Chl-a values comparison between field values and computed values in summer season.

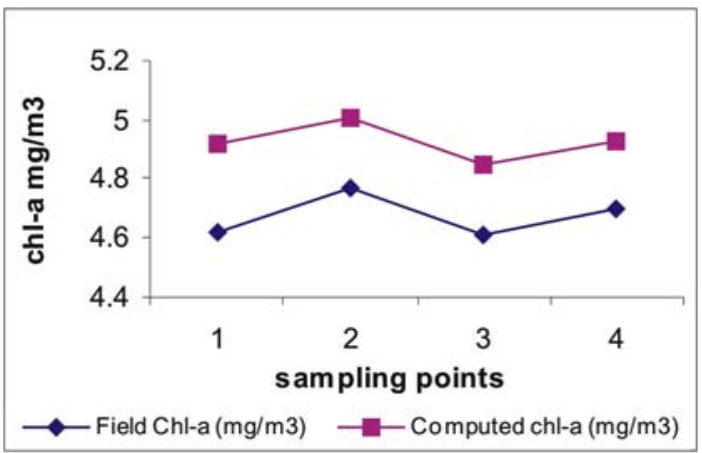

Fig. 10. SS values comparison between field values and computed values in summer season.

From the computed values it is seen that the chlorophyll-a was higher concentrations (4.85 to 5.04 $\mathrm{mg} / \mathrm{m}^{3}$ ) during the summer season and lower concentration (3.50 to $3.79 \mathrm{mg} / \mathrm{m}^{3}$ ) during monsoon season Fig. 11. and the suspended sediment concentration was higher (12.0 to $12.05 \mathrm{mg} / \mathrm{L}$ ) during the monsoon season and lower concentration (8.69 to 8.87 $\mathrm{mg} / \mathrm{L}$ ) during the summer season Fig. 12. This is due to the fresh water influx takes place from Cauvery distributaries during the winter season. The analysis indicates that the presence of high turbidity significantly reduced light penetration and limited photosynthesis. 


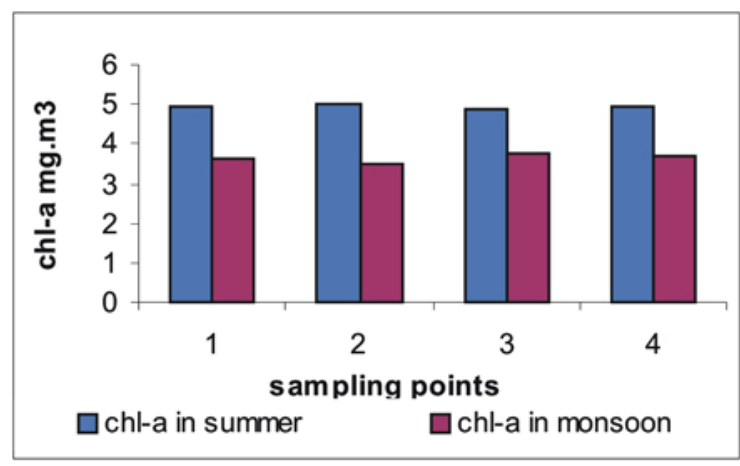

Fig. 11. Chl-a values concentration higher in summer season and lower in monsoon season.

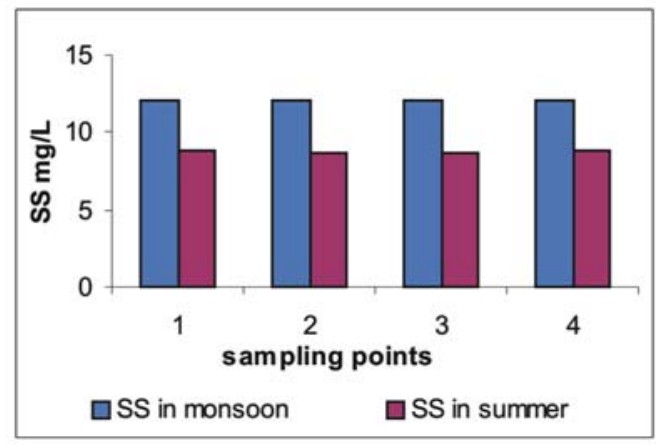

Fig. 12. SS values concentration higher in monsoon season and lower in summer season.

Thus, in the Vedaranyam Coast, phytoplankton production was mostly limited by light, rather than nutrients. Similar light-limited situations have been reported in San Francisco Bay (Alpine and Cloern, 1988), Satilla River Estuary (Lianyuan Zheng et al., 2004) and other estuaries (Cabecadas, 1999). From the algorithm, it is seen that, SS variations are not consistent with chl-a variation during the monsoon season, which is also evident from the in-situ data.

\section{CONCLUSION}

This is an attempt to apply the OCM sensor for developing an algorithm for coastal environment both in summer and monsoon season in Vedaranyam coast. The developed algorithms satisfy the Chl-a and SS concentration for two seasons at the site in coastal environmental conditions. In future, without the field sample values the concentration of Chl-a and SS can be estimated using this algorithm. However, in future more samples with temporal data representing different spectral characteristic of the coastal water is necessary for generalizing the algorithm.

\section{ACKNOWLEDGEMENT}

The authors thank the Department of Space, Govt. of India for sponsoring this project under RESPOND programme. The authors also express sincere gratitude to Dr.Shailesh Nayak, Group Director, Marine and Water Resources Division, SAC and R.M.Dwivedi, scientist "G", for their keen encouragement shown to carryout this work..

\section{REFERENCES}

[1] Alpine, A.E., Cloern, J.E. (1988) Phytoplankton growth-rates in a light-limited environment, San Francisco Bay. Mar. Ecol. Progr. Ser. 44, 167-173.

[2] Cabecadas, L. (1999), Phytoplankton production in the Tagus estuary (Portugal). Oceanol. Acta 22, 205-214.

[3] Camphell, J.W., O'Reukky, J.E. (1988), Role of satellites in estimating primary productivity on the northwest Atlantic continental shelf. Cot. Shelf res., 8, pp. 179-204.

[4] Chauhan.P., Nagur, C.R.C., Mohan, M., Nayak, S.R and Navalgund, R.R., 2001. Surface chlorophyll-a distribution in the Arabian Sea and Bay of Bengal using IRS-P4 Ocean Color Monitor satellite data Current Science, $802,127-129$

[5] Gordon, H.R. and Wang, M. (1994), Retrieval of water-leaving radiance and aerosol optical thickness over the oceans with SeaWiFS: A preliminary algorithm. Applied Optics, $33,443-452$.

[6] Lianyuan Zheng, Changsheng Chen, Frank Y. Zhang (2004), Development of water quality model in the Satilla River Estuary, Georgia 457-482.

[7] Mohan, M., Chauhan, P., Mathur, A and Dwivedi, R.M. 1998. Atmospheric correction of MOS-B data using long wavelength and PCl approachjes: IRSP3MOS validation experiment: OceanApplications. SAC Report No. SAC/RESA/MWRD/ IRSP3/SN/02/98, 14-22.

[8] Morel, A., Prieur, L. (1977), Analysis of Variations in ocean color. Limnol. Oceanogr., pp.709.722.

[9] Parsons, T.R., Y. Maita and C.M. Lalli (1989). A manual of chemical and Biological methods for seawater Analysis. Pergamon press, Oxford. 
[10] [Riche J.C., Charles, M.C. and Schiebe, F.R (1990). The relationship of MSS \&TM digital data with suspended sediments, chlorophyll and temperature in moon lake, Mississippi, Remote sens. Env., 33, pp. 137-148.

[11] Strickland, J. D. H., and Parsons, T. R. (1972), A Practical Handbook of Seawater Analysis. Fisheries Research Board of Canada, $310 \mathrm{pp}$.

[12] UNESCO, (1994) Protocols for Joint Global Ocean Carbon Flux Study (JGOFS) Core Measurements, Manuals and Guides. 29, 170 pp.

[13] Zhao, B. Y., He, B., Zhu, Y. Y., etc. (2000), remote sensing water quality model of suspended sediments in the dianchi lake water bodies. Environmental Science and Technology, 3(94), pp. 16-18(in Chinese).

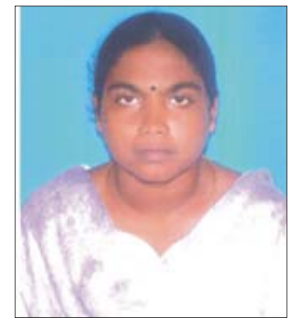

Ms. R. Nagalakshmi is a Research Scholar at the Institute of Remote Sensing, Anna University, Chennai. Her field of research is "Development of Regional BioOptical Algorithm for Wetland Management in Vedaranyam Coast using Remote Sensing and GIS". She is a post-graduate in Oceanography from Alagappa University, Karaikudi. 